IJLR: International Journal of Law Recontruction

Volume 5, Number 2, September 2021

DOI : http://dx.doi.org/10.26532/ijlr.v5i2.17945

\title{
THE LEGAL LIABILITY OF ONLINE DRIVER FOR PASSENGERS ACCIDENT IN CONSUMER PROTECTION LAW
}

\author{
Mariah Sonanggok Purba \\ Universitas Simalungun \\ mariapurba777@gmail.com \\ Fixma Raju Sinaga \\ Universitas Sumatra Utara \\ fixmaraju123@gmail.com
}

\begin{abstract}
Online motorcycle taxis have become a favorite public transportation for some people because they are flexible in their activities, can reach places that are not passed by public transportation such as city transportation (public transport), buses, or other types of four-wheeled public transportation. One of the losses experienced by passengers or motorcycle taxi service users is the occurrence of accidents caused by the mistakes of motorcycle taxi drivers. Legal certainty to provide protection to consumers in the form of protection of consumer rights, so that business actors do not act arbitrarily which always harms consumers. The research method used is normative juridical. The results of this study are that most of the Indonesian online motorcycle taxi companies use motorbikes as their means of transportation and receive payment for the services provided, not in accordance with what is stipulated in UULAJ and Government Regulation Number 74 of 2014 concerning Road Transportation. In order to operate the transportation of people not on a route using a public motorized vehicle, the public transportation company is required to have a license to operate the transportation of people not on a route which must meet the requirements. Legal protection for online motorcycle taxi passengers when an accident occurs is divided into 2, namely preventive and repressive legal protection.
\end{abstract}

Keywords: Accident; Consumer; Protection; Online; Motorcycle; Taxi.

\section{A. INTRODUCTION}

In a developing country, transportation has a very important role in encouraging the economy. Transportation in Indonesia is one element that plays an important role in encouraging the country's economy and promoting general welfare. Transportation is a process of moving people or goods from one place to another by using a land, sea, and air Vehicle. ${ }^{1}$

Transportation is used to make it easier for humans to carry out activities. So that all community activities can be fulfilled. In order to fulfill public transportation needs, the government is obliged to provide decent public transportation. Transportation is one of the facilities that have a very

1 Aminah, S, Transportasi Publik dan Aksesibilitas Masyarakat Perkotaan, Universitas Airlangga, Surabaya, 2006, page.24 
important role in expediting the wheels of the economy. The smooth running of the economy which has a chain of production, distribution and ends in consumption requires transportation facilities. ${ }^{2}$

The government has an obligation to ensure the availability of public transportation for the transportation of people and/or goods between cities, between provinces and across national borders, so that there is a balance between the availability of public transportation and the demand for public transportation. The existence of public transportation is very much needed, but if it is not handled properly and correctly it will become a problem for city life. ${ }^{3}$

The development of a civilization forces humans in it to move quickly, efficiently and effectively. Likewise, the fulfillment of human needs must also be fulfilled with efficient time, energy and costs. ${ }^{4}$ The development of this technology must also be followed by developments in Human Resources. Science and technology is always developing and progressing, in accordance with the times and the development of human thinking. The development of globalization and information technology has brought major changes in human life. Information Technology makes the relationship of communication between people and between nations easier and faster without being influenced by space and time. Globalization is a process of changing the dynamics of the global environment as a continuation of a situation that was previously characterized by the characteristics of technological and information progress, creating interdependence, blurring boundaries (borderless). ${ }^{5}$

Technology is the development and application of tools, machines, materials and processes that make it easier for humans to complete usually inseparable from information. Humans as technology users must be able to take advantage of current technology, as well as subsequent technological developments. Science and technology is always developing and progressing, in accordance with the times and the development of human thinking. ${ }^{6}$

Along with current technological developments, making various online application-based transportation services appear in Indonesia, several large companies are competing to form online application-based transportation companies, some of which are GO-JEK, Grab and Uber (nonapplicable). For some people, online transportation is a solution to a transportation system that is still bad, but on the other hand it is a problem

2 Fardan, Tanggung Jawab Pengangkut Terhadap Penumpang Pada Angkutan Jalan Menurut Undang-Undang Nomor 22 Tahun 2009, Legal Opinion, Vol 1 No 1, 2013, page.1-11

3 Abbas Salim, H.A, Manajemen Transportasi, Raja Grafindo Persada, Jakarta, 2006, page. 11

4 Ukie Tukinah, Model Perlindungan Preventif Bagi Konsumen Onlineshop Melalui Keterbukaan Informasi, Jurnal Pembaharuan Hukum, Vol II No.3 September-December 2015, page.388399

5 Massulthan Rafi Wijaya, Ridwan Arifin, Cyber Crime in International Legal Instrument: How Indonesia and International Deal with This Crime?, Indonesian Journal of Criminal Law Studies (IJCLS), Vol.5 (1) (2020) page.63-74

6 Gunadi, Teknologi Wireless Lan dan Aplikasinya, Elex Media Komputindo, Jakarta, 2006, page. 6 
for people who depend on transportation services that do not rely on technology. Online transportation offers convenience, lower costs, more comfort and security, so it is not surprising that many people are switching from conventional transportation modes to online transportation modes. Over time, the presence of this online transportation creates social jealousy for the conventional transportation that has existed before, both motorcycle taxis, taxis, buses and so on. ${ }^{7}$

The online transportation application classifies the online transportation driver accounts. The division of accounts is based on the performance and professionalism of the driver. Driver account types are divided into priority account types, normal accounts, and non-priority accounts. Priority account is an account that is very easy to get job orders, drivers with priority accounts get jobs repeatedly, this is very beneficial for drivers because they will get a large income from service payments and will get bonuses with less than 8 hours of working time Normal account type getting orders is not as busy as priority. ${ }^{8}$ Online motorcycle taxis have become a favorite public transportation for some people because they are flexible in their activities. De facto, the existence of motorcycle taxis is considered to be very helpful for the community in solving obstacles to the availability of public transportation as an alternative transportation. However, de jure, the existence of motorcycle taxis is considered problematic in terms of legality, because normatively there is no law that clearly regulates motorcycle taxis.

This online-based mode of transportation leaves problems sparking pros and cons in the community, for those who contra consider this onlinebased mode of transportation illegal because it does not meet the provisions of the applicable laws and regulations regarding road traffic and transportation which must have the required business license as a company that operates. ${ }^{9}$ The absence of specific regulations regarding motorcycle taxis in Act No. 22 of 2009 concerning the Traffic and Road Transport Law as well as Government Regulation Number 74 of 2014 concerning Road Transportation has resulted in legal uncertainty related to the position of motorcycle taxis as people's transportation by public motorized vehicles. This also results in the responsibility of motorcycle taxis towards their use in terms of the traffic law and road transportation, because on the one hand the traffic and road transportation law regulates vehicles in Article 1 paragraph (10) which states that public motorized vehicles is any vehicle used to transport goods and/or people for a fee. Consumers must be legally protected through clear and definite legislation, including settlements that

7 Ayu Aziah, Popon Rabia Adawia, Analisis Perkembangan Industri Transportasi Online di Era Inovasi Disruptif (Studi Kasus PT GO-JEK Indonesia), Cakrawala Jurnal Humaniora bina sarana Informatika, Vol 18 No. 2 September 2018, page.149-156

8 Mahmud Yunus, Etty Soesilowati, Dewi Liesnoor Setyowati, Thriwaty Arsal, Can Online Transportation Applications Improve Driver Professionalism?, International Journal of Scientific \& Technology Research, Vol 9, Issue 02, February 2020, page.3155-3159

9 Hanifah Sartika Putri, Amalia Diamantina, Perlindungan Hukum Terhadap Keselamatan Dan Keamanan Pengemudi Ojek Online Untuk Kepentingan Masyarakat, Jurnal Pembangunan Hukum Indonesia, Vol 1, No.3, 2019, page.392-403 
can be taken by consumers if they experience losses on the operation of public transportation services for motorcycle taxis.

One of the losses experienced by passengers or motorcycle taxi service users is the occurrence of accidents caused by the mistakes of motorcycle taxi drivers. Legal certainty to provide protection to consumers in the form of protection of consumer rights, so that business actors do not act arbitrarily which always harms consumers.

Users of motorcycle taxi services can be referred to as consumers because in Act No. 8 of 1999 concerning Consumer Protection in Article 1 paragraph (2) it states "Consumers are every person who uses goods and / services available in the community, both for their own interests family, other people or other living things and are not for trade. ${ }^{\prime 10}$ Consumers must be legally protected through clear and definite legislation, including settlements that can be taken by consumers if they experience losses on the operation of public transportation of motorized motorcycle taxis. One of the losses experienced by passengers or motorcycle taxi service users is the occurrence of accidents caused by motorcycle taxi drivers. Legal certainty to provide protection to consumers in the form of protection of consumer rights, so that business actors do not act arbitrarily that harm consumers.

The purpose of this study is to find out and analyze the legal obligations of online drivers to Passengers Accident in consumer protection law, besides that this research is expected to provide knowledge about legal certainty to provide protection to consumers in the form of protection of consumer rights, so that business actors do not act arbitrarily that harms consumers.

\section{B. RESEARCH METHODS}

The approach method used in this study is a normative juridical approach (normative legal research), ${ }^{11}$ namely this study examines the applicable laws and regulations. The subject of the study is the law which is conceptualized as a norm or rule that applies in society and becomes a reference for everyone's behavior. So that normative legal research focuses on an inventory of positive law, legal principles and doctrines, legal findings in cases in concreto, legal systems, synchronization levels, legal comparisons and legal history. ${ }^{12}$

\section{RESULT AND DISCUSSION}

\section{The Legal Liability of Online Driver For Passengers Accident In Consumer Protection Law}

Every legal relationship has two aspects, namely rights and obligations. Rights and obligations arise from a legal event and the

10 Alfis Setyawan, Deeky Agus Sufandy, Analisis Perlindungan Hukum Terhadap Konsumen Pengguna Jasa Ojek Online di Kota Batam, Journal of Judicial Review, Vol. XX No. 1 (2018), page.17-34

11 Soerjono Soekanto dan Sri Mamudji, Penelitian Hukum Normatif, Rajawali Press, Jakarta, 1990, page. 18.

12 Abdulkadir Muhammad, Hukum dan Penelitian Hukum. Cet. Ke-1. PT. Citra Aditya Bakti, Bandung, 2004, page. 52. 
disappearance of rights and obligations also coincide. The legal relationship has three elements, namely the existence of the parties, the object, and the relationship between the owner of the right and the bearer of the obligation or the relationship to the object in question. So it can be concluded that the legal relationship exists if there is a legal basis that regulates the legal relationship and the emergence of legal events. ${ }^{13}$

Consumers in using GO-JEK application services, which are actually through driver partners, are full of risks on the road, such as the nonfulfillment of consumer rights in the UUPK. As stated in Article 4 paragraph letter a of the UUPK "The right to comfort, security and safety in consuming goods and/or services". If the incident occurs, the public needs to know that there is legal protection if when using an online motorcycle taxi service there is an accident on the highway, in this case it is not clear that there are regulations regarding motorized motorcycle taxis, so if this accident occurs it is a pure accident, because GO-JEK has not registered as public transportation and there is no legal basis yet, it's just that GO-JEK and other transportation service companies are allowed to operate through the tweets of the President of the Republic of Indonesia, Joko Widodo on one of the social media ${ }^{14}$ which essentially gave an order from the Minister of Transportation to allow online transportation services to continue to operate, because the Indonesian people really needed it.

After the statement of the President of the Republic of Indonesia above, the Minister of Transportation Regulation Number 108 of 2017 appears again concerning the Implementation of Transportation of People With Public Motorized Vehicles Not On Routes. The regulation is an answer to doubts about regulations regarding online-based motorcycle taxis. Various facilities for public transportation operators with information technology-based applications have been described in Article 63 paragraphs (1) and (3) of the Minister of Transportation Regulation Number 108 of 2017 which reads "to increase the ease of ordering transportation services for people not on routes, public transportation companies can use information technology-based applications" and in paragraph (3) which reads "to increase the ease of payment for services for transportation of people not on the route, public transportation companies can make payments in cash or use information technologybased applications."

GO-JEK has received a SIUP (Trade Business Permit) and SITU (Business Stay Permit) but there is no operational permit from the Transportation Agency. If an accident occurs, the driver or partner of GO-JEK is responsible for the accident, so The Department of Transportation is not responsible.

13 Aulia Fikrina, Firdaus, Ulfia Hasanah, Perjanjian Antara Pengemudi GO-JEK Dengan Pemilik Provider GO-JEK (Studi Terhadap Hak Dan Kewajiban Para Pihak Dalam Perjanjian), JOM Fakultas Hukum Universitas Riau Vol VII No 1Januari-Juni 2020, page.1-15

14 Andika Wijaya, Aspek Hukum Bisnis Transportasi Jalan Online, Sinar Grafika, Jakarta, 2016, page. 200 
GO-JEK has not officially become public transportation, because GO-JEK has not met the requirements for establishing a public transportation company, because this will become a source of administrative law for the GO-JEK company and the Department of Transportation can be responsible if there is an accident on the highway or other problems. The problems that arise within GO-JEK itself are related to public services as public motorized vehicles that have been legal and recognized by the government, especially the Department of Transportation as the manager of road transportation.

Despite the unclear status of public transportation from online transportation, passengers who use online transportation services still get legal protection through Act No. 8 of 1999 concerning Consumer Protection if they experience an event. Act No. 8 of 1999 states that: Business actors are responsible for providing compensation for damage, pollution, and/or consumer losses due to consuming goods and/or services produced or traded. So the online transportation company (business actor) is responsible if the passenger (service user) experiences an event such as an accident or crime when using the online transportation. ${ }^{15}$

In the work agreement between PT GO-JEK and the Partner, it also states that the Partner hereby frees PT GO-JEK from all kinds of claims, lawsuits, or other legal actions, both in a civil lawsuit and any criminal charges experienced by the Partner in any form related to with the services offered or provided through the GO-JEK application. If there is information that can help in the investigation process such as license plates, then PT GO-JEK can only help as a mediator in bringing together the two parties to find a solution to the problem. ${ }^{16}$

Associated with standard clauses, based on Article 18 paragraph (1) UUPK, inclusion of standard clauses by business actors is prohibited. And based on Article 18 paragraph (3) of the UUPK, the clause is null and void, so the provisions in the policy containing clauses that are difficult to understand and the transfer of responsibility are deemed to have never had a consequence, the agreement does not protect consumers.

Based on Article 234 paragraph (1) of Act No.22 of 2009 concerning Road Traffic and Transportation "the driver, motorized vehicle owner, and/or public transportation company are responsible for the losses suffered by the passengers and/or the owner of the goods and/or third parties due to driver negligence". With the above laws and regulations, it is clear that the GO-JEK company must be responsible for the losses suffered by the GO-JEK passengers.

In UUPK Article 4 paragraph (5) it is explained that consumers are entitled to proper advocacy, protection, and dispute resolution efforts, so consumers are entitled to legal protection. Legal protection is divided into

15 Margaretha Evelin Asmara Putri, Moch. Najib Imanullah, Tanggung Gugat Perdata Angkutan Umum Berbasis Online Terhadap Penumpang Apabila Terjadi Suatu Kecelakaan Lalu Lintas, Jurnal Privat Law, Vol. VII No 2 July - December 2019, page.223-227 
2, namely preventive and repressive legal protection:

a. Preventive Legal Protection

Preventive legal protection, namely preventive legal protection, legal subjects are given the opportunity to submit their objections or opinions before a government decision gets a definitive form. The goal is to prevent disputes. ${ }^{17}$

According to Article 235 paragraph (1) UULAJ which reads "if the victim dies due to a traffic accident as referred to in Article 229 paragraph (1) letter $c$, the driver, owner, and/or public transportation company must provide assistance to the victim's heirs in the form of medical expenses. and/or funeral expenses without dismissing the criminal case, and according to Article 235 paragraph (2) which reads "if there is an injury to the body or health of the victim due to a traffic accident as referred to in Article 229 paragraph (1) letter $b$ and letter c, drivers, owners, and/or public transportation companies are required to provide assistance to victims in the form of medical expenses without dropping the criminal case charges.

Article 7 paragraph (6) of the UUPK which reads that "business actors are obliged to provide compensation, compensation, and/or compensation for losses due to the use, use, and utilization of traded goods and/or services". Meanwhile, Article 60 paragraph (1) of the UUPK reads "The Consumer Dispute Settlement Agency has the authority to impose administrative sanctions on business actors who violate Article 19 paragraph (2) and paragraph (3), Article 20, Article 25 and Article 26."

Paragraph (2) which reads "administrative sanctions in the form of stipulation of compensation for a maximum of IDR $200,000,000.00$ (two hundred million rupiah)" and paragraph (3) which reads "the procedure for determining administrative sanctions as referred to in paragraph (1) shall be further regulated in the laws and regulations".

b. Repressive Legal Protection

Repressive legal protection is aimed at resolving disputes by focusing on efforts to take action or punishment. This effort gives an important role in the involvement of law enforcement agencies which is carried out by streamlining the function of legal sanctions in the form of civil sanctions, criminal sanctions and administrative sanctions. ${ }^{18}$

Based on the above regulations, GO-JEK passengers can sue the GO-JEK driver partner and also the GO-JEK company itself for losses suffered by the consumer, and the Traffic Police can also

17 Wahyu Simon Tampubolon, Upaya Perlindungan Hukum Bagi Konsumen Ditinjau Dari Undang-Undang Perlindungan Konsumen, Jurnal IImiah Advokasi Vol. 04. No. 01. March 2016, page.53-61

18 I Putu Pasek Bagiartha W, Kepastian Perlindungan Hukum Bagi Konsumen Atas Pemberlakuan Kontrak Baku, Jurnal IUS Kajian hukum dan Keadilan, Vol 1 No 1 April 2013, page.60-76 
help the consumer or GO-JEK passenger in the event of an accident on the road highway and claim compensation for the negligence of the driver and the GO-JEK company.

\section{The Legal Protection of Consumer Rights}

The form of legal protection between business actors or companies providing online motorcycle taxi services and online motorcycle taxi drivers is a partnership relationship, not a working relationship between employers and workers. The cooperative relationship between companies through a partnership pattern cannot be separated from the law of agreement between the parties, which is based on the principle of freedom of contract as regulated in Article 1338 paragraph (1) of the Civil Code, which states that all contracts (agreements) made are validly valid as law for those who make it. The existence of an agreement will give rise to rights and obligations for each party, including legal consequences if there are parties who violate the agreement or do not fulfill their obligations. Here the law functions to provide signs or rules so that the cooperation that has been established through the collective agreement deed can run well. ${ }^{19}$ So, the responsibility that online transportation companies give to consumers on the basis of mutually beneficial relationships.

Everyone, both drivers and customers, are entitled to legal protection when making transactions in any form. The number of promos every day makes people interested in using the services of this company such as free shipping services or a discount of a few percent from where customers buy goods. The rights and obligations of drivers are determined by the company, their obligations are to prioritize the interests of customers and maintain good trust, their rights are to get more wages than the company.

The definition of a consumer according to Article 1 paragraph (2) of the UUPK is every person who uses goods/services, which are available in the community, both for the benefit of themselves, their families, other people, and other living creatures and are not for trading, explaining that based on Article 1 paragraph (1) UUPK understanding consumer protection is all efforts that guarantee legal certainty to provide protection to consumers. From this understanding, it can be concluded that the relationship between consumers and business actors is basically a legal relationship that creates mutual rights and obligations between the two.

The reasons for regulating consumer protection are motivated by consumer rights, namely (1) creating a consumer protection system that contains access and information, as well as guaranteeing legal certainty; (2) protecting the interests of consumers in particular and the interests of all business actors in general; (3) increasing quality of goods and services; (4) provide protection to consumers from deceptive and

19 Absori, Hukum Ekonomi di Indonesia: Beberapa Aspek Pengembangan Pada Era Liberalisasi Perdagangan, Muhammadiyah University Press, Surakarta, 2014, page. 75. 
misleading business practices; and (5) integrating the implementation, development and regulation of consumer protection with other fields of protection.

Based on Article 2 of the UUPK, there are 5 (five) principles in consumer protection, namely (1) the principle of benefit, (2) the principle of justice, (3) the principle of balance, (4) the principle of consumer safety and security, and (5) the principle of legal certainty. ${ }^{20}$

a. The principle of benefit, mandates that all efforts in the implementation of consumer protection must provide the maximum benefit for the protection of consumers and business actors as a whole.

b. The principle of justice, mandates that the participation of all people can be realized maximally and provides opportunities for consumers and business actors to obtain their rights and carry out their obligations fairly.

c. The principle of balance, mandates to provide a balance between the interests of consumers, business actors and the government in the material and spiritual sense.

d. The principle of security and safety, mandates to provide guarantees for security and safety to consumers in the use, use, utilization of goods or services that are consumed or used.

e. The principle of legal certainty, mandates that both business actors and business actors obey the law and obtain justice in the implementation of consumer protection and the State guarantees legal certainty.

Article 3 of the UUPK regulates the legal objectives of consumer protection, as follows:

a. Increase consumer awareness, ability, and independence to protect themselves.

b. Raise the dignity of consumers by preventing them from the negative excesses of using goods and/or services;

c. Increase consumer empowerment in choosing, determining and demanding their rights as consumers.

d. Creating a consumer protection system that contains elements of legal certainty and information disclosure as well as access to information.

e. Growing awareness of business actors on the importance of consumer protection so that an honest and responsible attitude in doing business grows.

f. Improving the quality of goods and/or services that ensure the continuity of the business of producing goods and/or services, health, comfort, security and safety of consumers.

The Constitutional Court refused to legalize the existence of online

20 Abdul Halim Barkatullah, Hukum Perlindungan Konsumen, Nusa Media, Bandung, 2008, page. 27 
motorcycle taxis as a legal means of transportation. After the issuance of the Constitutional Court's decision No. 41/PUU-XVI/2018 that online motorcycle taxi drivers have been given legal protection for security rights and the right to work and a decent living, it is increasingly threatened because in the Constitutional Court's decision that online motorcycle taxi drivers are not included in public transportation, then the government has the consequence of not having the authority to regulate this online motorcycle taxi, besides that it is not recognized in the traffic and road transportation law. That the legal relationship between GO-JEK partners and PT. GO-JEK Indonesia only has a partnership agreement, namely where the legal relationship between PT. GO-JEK Indonesia with GO-JEK partners that underlie the partnership relationship. ${ }^{21}$

There are no clear rules regarding online motorcycle taxis or motorcycle taxis themselves so that if an accident occurs, the person responsible for the accident is the online motorcycle taxi driver himself. The Department of Transportation as the transport policy holder is not responsible. Online motorcycle taxis have not officially become public transportation because online motorcycle taxis have not met the requirements for establishing a public transportation company. The conditions for the establishment of a public transportation company will be a source of administrative law for online motorcycle taxi companies and the Department of Transportation can be responsible if there is an accident on the highway or problems that arise within the online motorcycle taxi itself. These problems include those related to public services as public motorized vehicles that have been legal and recognized by the government, especially the Department of Transportation as the manager of road transportation.

The contract between PT. GO-JEK Indonesia with drivers made electronically. Electronic contracts made by business managers contain several articles of partnership cooperation which are made standard and are applied equally to all their partners. The interesting thing in electronic contracts is that there are several articles in the terms of the agreement that are not beneficial for the work partner and there is no room for the work partner to conduct reviews, rebuttals and offers as part of the elements of the agreement in the agreement. If the GO-JEK driver partner agrees with the contents contained in the electronic contract, the driver simply presses the click button provided in the electronic contract. $^{22}$ The work agreement between GO-JEK and partners also states, partners hereby free GO-JEK from all kinds of demands, lawsuits, or other legal actions, both in a civil lawsuit and any criminal charges experienced by partners in any form related to the services offered or provided through the GO-JEK application. If there is information that can

21 Putu Mahendra Wijaya, Ida Ayu Sukihana, Perlindungan Hukum Terhadap Mitra GO-JEK Atas Tindakan Konsumen Yang Melakukan Orderan Fiktif Go-Shop, Jurnal Kertha Negara Vol. 9. No. 2. 2021, page. 120-129

22 Ruslan Haerani, Perjanjian Kemitraan Antara PT. GO-JEK Indonesia Dengan Driver Transportasi Berbasis Teknologi Di Pulau Lombok (Study di Pulau Lombok), Jurnal Res Justitia, Vol 1 Nomor 2 July 2021, page.157-167 
help in the investigation process such as license plates, then GO-JEK can only help as a mediator in bringing the two parties together to find a solution to the problem.

The results of research conducted by Dhevi Nayasari stated that the form of responsibility of the GO-JEK driver for the accident was in the form of compensation to the passenger. Meanwhile, GO-JEK provides accident compensation to all GO-JEK customers who use Go-Ride (People's Transport Services) services. Passengers will receive reimbursement up to IDR $10,000,000$, and for hospital fees up to IDR $5,000,000$, the nominal with terms and conditions apply. ${ }^{23}$ Consumers must be legally protected through clear and definite legislation, including settlements that can be taken by consumers if they experience losses on the operation of public transportation services for motorcycle taxis. ${ }^{24}$

In the implementation of transportation business activities which are carried out by driver partners or as business actors who partner with PT. GO-JEK Indonesia as an application service provider with passengers, namely as the consumer or the party using the service. These business activities do not always fulfill the rights of consumers. As stated in Article 4 paragraph (1) of the UUPK, namely "Consumers have the right to comfort, security, and safety in consuming goods and/or services". Which in this transportation service activity is not always achieved or consumers as service users experience losses. In accordance with the Traffic and Road Transport Law and the Consumer Protection Act, the consumer has the right to obtain compensation from business actors. However, business actors are not always able to complete their responsibilities so that obstacles arise in the implementation of business actors in fulfilling their responsibilities.

\section{CONCLUSION}

Legal protection for online motorcycle taxi passengers when an accident occurs is divided into 2 , namely preventive and repressive legal protection. Preventive legal protection is that legal subjects are given the opportunity to submit their objections or opinions before a government decision gets a definitive form. Repressive legal protection aims to resolve disputes, the handling of legal protection by general courts and administrative courts in Indonesia is included in this category of legal protection. Based on the applicable law in Indonesia, because PT. GO-JEK is only an application provider company that connects consumers with service providers, namely drivers, so drivers must be responsible on the basis of Article 1365 of the Civil Code which states "Every act that violates the law and causes harm to others, requires the person who caused the loss because of his mistake. to compensate for the loss" and Article 19 paragraph (1) of the UUPK which states "Business actors are responsible for

23 Dhevi Nayasari Sastradinata, Aspek Pertanggungjawaban Pengemudi Ojek Online Dalam Kasus Kecelakaan Yang Melibatkan Penumpang Dilihat Dari Hukum Perlindungan Konsumen, Jurnal Independent, Vol 6, No 2 (2018), page.113-119

24 Andika Wijaya, Op.Cit, page.10 
providing compensation for damage, pollution, and or consumer losses due to consuming goods and or services produced or traded."

\section{BLIBIOGRAPHY}

\section{Books:}

Abbas Salim, H.A, 2006, Manajemen Transportasi, Raja Grafindo Persada, Jakarta;

Abdul Halim Barkatullah, 2008, Hukum Perlindungan Konsumen, Nusa Media, Bandung;

Absori, 2014, Hukum Ekonomi di Indonesia: Beberapa Aspek Pengembangan Pada Era Liberalisasi Perdagangan, Muhammadiyah University Press, Surakarta;

Abdulkadir Muhammad, 2004, Hukum dan Penelitian Hukum. Cet. Ke-1. PT. Citra Aditya Bakti, Bandung;

Aminah, S, 2006 Transportasi Publik dan Aksesibilitas Masyarakat Perkotaan, Universitas Airlangga, Surabaya;

Andika Wijaya, 2016, Aspek Hukum Bisnis Transportasi Jalan Online, Sinar Grafika, Jakarta;

Gunadi, 2006, Teknologi Wireless Lan dan Aplikasinya, Elex Media Komputindo, Jakarta;

Soerjono Soekanto dan Sri Mamudji, 1990, Penelitian Hukum Normatif, Rajawali Press, Jakarta.

\section{Journals:}

Alfis Setyawan, Deeky Agus Sufandy, Analisis Perlindungan Hukum Terhadap Konsumen Pengguna Jasa Ojek Online di Kota Batam, Journal of Judicial Review, Vol. XX No. 1 2018;

Aulia Fikrina, Firdaus, Ulfia Hasanah, Perjanjian Antara Pengemudi GO-JEK Dengan Pemilik Provider GO-JEK (Studi Terhadap Hak Dan Kewajiban Para Pihak Dalam Perjanjian), JOM Fakultas Hukum Universitas Riau Vol VII No 1Januari-Juni 2020;

Ayu Aziah, Popon Rabia Adawia, Analisis Perkembangan Industri Transportasi Online di Era Inovasi Disruptif (Studi Kasus PT GO-JEK Indonesia), Cakrawala Jurnal Humaniora bina sarana Informatika, Vol 18 No. 2 September 2018;

Dhevi Nayasari Sastradinata, Aspek Pertanggungjawaban Pengemudi Ojek Online Dalam Kasus Kecelakaan Yang Melibatkan Penumpang Dilihat Dari Hukum Perlindungan Konsumen, Jurnal Independent, Vol 6, No 2 (2018); 
Fardan, Tanggung Jawab Pengangkut Terhadap Penumpang Pada Angkutan Jalan Menurut Undang-Undang Nomor 22 Tahun 2009, Legal Opinion, Vol 1 No 1, 2013;

Hanifah Sartika Putri, Amalia Diamantina, Perlindungan Hukum Terhadap Keselamatan Dan Keamanan Pengemudi Ojek Online Untuk Kepentingan Masyarakat, Jurnal Pembangunan Hukum Indonesia, Vol 1, No.3, 2019;

I Putu Pasek Bagiartha W, Kepastian Perlindungan Hukum Bagi Konsumen Atas Pemberlakuan Kontrak Baku, Jurnal IUS Kajian hukum dan Keadilan, Vol 1 No 1 April 2013;

Mahmud Yunus, Etty Soesilowati, Dewi Liesnoor Setyowati, Thriwaty Arsal, Can Online Transportation Applications Improve Driver Professionalism?, International Journal Of Scientific \& Technology Research, Vol 9, Issue 02, February 2020;

Margaretha Evelin Asmara Putri, Moch. Najib Imanullah, Tanggung Gugat Perdata Angkutan Umum Berbasis Online Terhadap Penumpang Apabila Terjadi Suatu Kecelakaan Lalu Lintas, Jurnal Privat Law, Vol. VII No 2 July - December 2019

Massulthan Rafi Wijaya, Ridwan Arifin, Cyber Crime in International Legal Instrument: How Indonesia and International Deal with This Crime?, Indonesian Journal of Criminal Law Studies (IJCLS), Vol.5 (1) (2020);

Putu Mahendra Wijaya, Ida Ayu Sukihana, Perlindungan Hukum Terhadap Mitra GO-JEK Atas Tindakan Konsumen Yang Melakukan Orderan Fiktif Go-Shop, Jurnal Kertha Negara Vol. 9. No. 2. Tahun 2021;

Ruslan Haerani, Perjanjian Kemitraan Antara PT. GO-JEK Indonesia Dengan Driver Transportasi Berbasis Teknologi Di Pulau Lombok (Study di Pulau Lombok), Jurnal Res Justitia, Vol 1 Nomor 2 July 2021;

Ukie Tukinah, Model Perlindungan Preventif Bagi Konsumen Onlineshop Melalui Keterbukaan Informasi, Jurnal Pembaharuan Hukum, Vol II No.3 September-December 2015;

Wahyu Simon Tampubolon, Upaya Perlindungan Hukum Bagi Konsumen Ditinjau Dari Undang-Undang Perlindungan Konsumen, Jurnal IImiah Advokasi, Vol. 04. No. 01. March 2016; 